\title{
COMPARISON OF THE 2D-3D GRAVITY CALCULATIONS IN CARTESIAN COORDINATES AND 3D IN CARTESIAN-SPHERICAL COORDINATES
}

\author{
Hasan Çavşak, Ali Elmas* \\ Karadeniz Technical University, Faculty of Engineering, Department of Geophysical Engineering \\ 61080 Trabzon /Turkiye \\ cavsak@ktu.edu.tr; $\underline{\text { elmas@ktu.edu.tr }}$
}

\begin{tabular}{l}
\hline Keywords \\
\hline Anomaly, \\
Gravity, \\
Inversion, \\
Modelling
\end{tabular}

\section{B-3B GRAVITTE HESAPLAMALARININ KARTEZYEN KOORDİNATLARDA VE 3B OLARAKTA KARTEZYEN-KÜRESEL KOORDİNATLARDA KARŞILAŞTIRILMASI}

\begin{tabular}{l}
\hline Anahtar Kelimeler \\
\hline Anomali; \\
Gravite; \\
Ters çözüm; \\
Modelleme.
\end{tabular}

* Corresponding Author: Ali Elmas, +90-462-377-3429

\begin{abstract}
Özet
$\mathrm{Bu}$ çalışmada, gravite hesabında en iyi sonuca ulaşmak için çeşitli hesaplamaların karşılaştırılması yapıldı. Üç boyutlu (3B) gravite çalışmasında, kütle yüzeyleri üçgen yüzeylere bölünerek tanımlandı. Tanımlamada mümkün olduğunca fazla üçgen yüzey kullanılarak, daha hassas kütle tanımlaması yapıldı. 3B ana model olarak üçgen piramitler dikkate alındı. Bu model, her bir üçgen yüzey ile hesap noktası arasında oluşturuldu. Bu model, karmaşık şekilli birimleri mükemmel olarak tanımlayabilir. $\mathrm{Bu}$ çalışmada, iki boyutlu (2B) ve 3B gravite hesaplamaları, kartezyen koordinatlarda uygun bir sentetik model kullanılarak karşılaştırıldı. İkinci çalışmada da, 3B gravite hesaplamaları, kartezyen ve küresel koordinatlarda uygun bir sentetik model kullanılarak karşılaştırıldı. Birinci çalışmada, 3B gravite hesaplamalarının sonuçlarının doğruluğu, kartezyen koordinatlarda ters çözüm ile bulunur. İkinci çalışmada da, 3B gravite hesaplamalarının doğruluğu, kartezyen ve küresel koordinatlarda bulunur. Bu iki çalışmada, düz ve ters çözümler, bu model geometriler için yoğunluk kabulüyle, özel bir algoritma kullanılarak yapılır. Gravite yönteminde, en iyi sonuçlara, küresel koordinatlarda 3B gravite ters çözüm hesabıyla ulaşılır.
\end{abstract}




\section{Introduction}

The gravity method is applied in petroleum search, oil-related construction, to bring out fault and salt structure, to help seismic surveys [1, 12, 13]. In addition, the gravity method is used to examine various tectonic units, to uncover major fault systems, to investigate magmatic mass limit in the basin is covered by younger layers, to examine the thickness of earth crust and structure [15, 17]. The world-wide geophysical research is done mostly with 2D subsurface modeling. of course, the results are trusted level. However, the 3D subsurface modeling can never be compensated by 2D models. Though 2D models require less data and time, it should be directed to 3D subsurface modeling requires more data and effort. The $3 \mathrm{D}$ gravity study in spherical coordinates is more accurate than the 3D gravity study in cartesian coordinates. By this study, it is explained that Earth's curvature should be considered in the 3D gravity computations.

\section{Materials and Methods}

The geophysical research is done mostly with 2D subsurface modeling $[3,6,10,16]$. Sometimes, the geophysical research is done with 3D subsurface modeling $[4,5,6,7,8,9$, $11,14]$. The 3D gravity algorithm is explained with outlines. The outlines of the 3D gravity algorithm are obtained from the Ph.D. Thesis [2]. Parameters in equation are obtained after coordinate transformation [3] and shown in Fig.1. 3D model geometry is triangulated to describe the whole surface of the mass. Three points define planes, and the method is the most convenient one for 3D modeling [14]. Even for very complicated mass shapes, a good description can be obtained by increasing the number of triangles. The gravity effects of the bodies is calculated first for the tetrahedra expanded by an "observation" point $P$ to each triangle and then adding them all up in a certain sequence ([9], Fig. 2, Eq.(1) to 10; [3]). The surface of a uniform 3D body can be well approximated as a polyhedron of plane triangles to any degree of detail. This parametrization is flexible and efficient.
Figure 2 shows the basic uniform tetrahedron used to calculate the gravitational potential $d \mathrm{U}$ and to the gravity effect $d \mathrm{~g}$ at its apex P. The tetrahedron from $P$ to an arbitrarily oriented planar triangle $\mathrm{ABC}$ is numbered $\mathrm{k}$. Without reducing generality, $\mathrm{P}$ can be placed at the origin $\mathrm{O}$ of the earth-oriented Cartesian ( $x, y, z)$ coordinate system with $\mathrm{z}$ pointing vertically downward. The desired gravity effect of the polyhedron is derived as the vertical component of the potential gradient. The effects, $d \mathrm{~g}$ and $d \mathrm{U}$, of the polyhedron are the sums of all the basic tetrahedral effects. With a consistently defined sequence of computational steps, the partial effects are automatically calculated with the correct sign, i.e. positive for "far-side" triangles and negative for "near-side" triangles; "near" and "far" signify the geometrical relation of the observation point $\mathrm{P}$ and the polyhedron. The far-side basic tetrahedral effects are added, while the near-side tetrahedral effects are subtracted such that only the effects of the intervening polyhedron are remaining. The calculations are also correct if $\mathrm{P}$ is enclosed in a polyhedron. Integration of the tetrahedral potential effect, dU, in arbitrary orientation is awkward, but for the scalar potential the orientation is irrelevant and therefore a suitable coordinate transformation is carried out: $\xi, \eta, \zeta$ is defined such that the triangle is in the plane and one edge (1-2) is parallel to $\xi$ (Fig. 2). A FORTRAN code has been developed which performs the triangulation and the integration [2]. It is unnecessary to evaluate the complicated term, and the simpler expression speeds up the evaluation of $\mathrm{dg}$ and increases the numerical accuracy. Completely written, the expression is fairly complex.

$$
\Delta U=\frac{G \cdot \rho}{h} \int_{\eta_{A}}^{\eta_{C}} \int_{\xi^{(1)}}^{\xi^{(2)}} \int_{\zeta=0}^{h} \frac{\zeta \cdot d \zeta \cdot d \xi \cdot d \eta}{\left(\xi^{2}+\eta^{2}+h^{2}\right)^{1 / 2}}
$$

where $h$ is height of tetrahedral; $\xi, \eta$ and $\zeta$ are the coordinate values that define tetrahedral ( Fig.2). 
With an analytical solution of Eq.(1), we obtain;

$$
\Delta U=\frac{1}{2} G \cdot \rho \cdot h \cdot F(\eta, \xi)
$$

$F(\eta, \xi)$ is defined with Eq.(3),

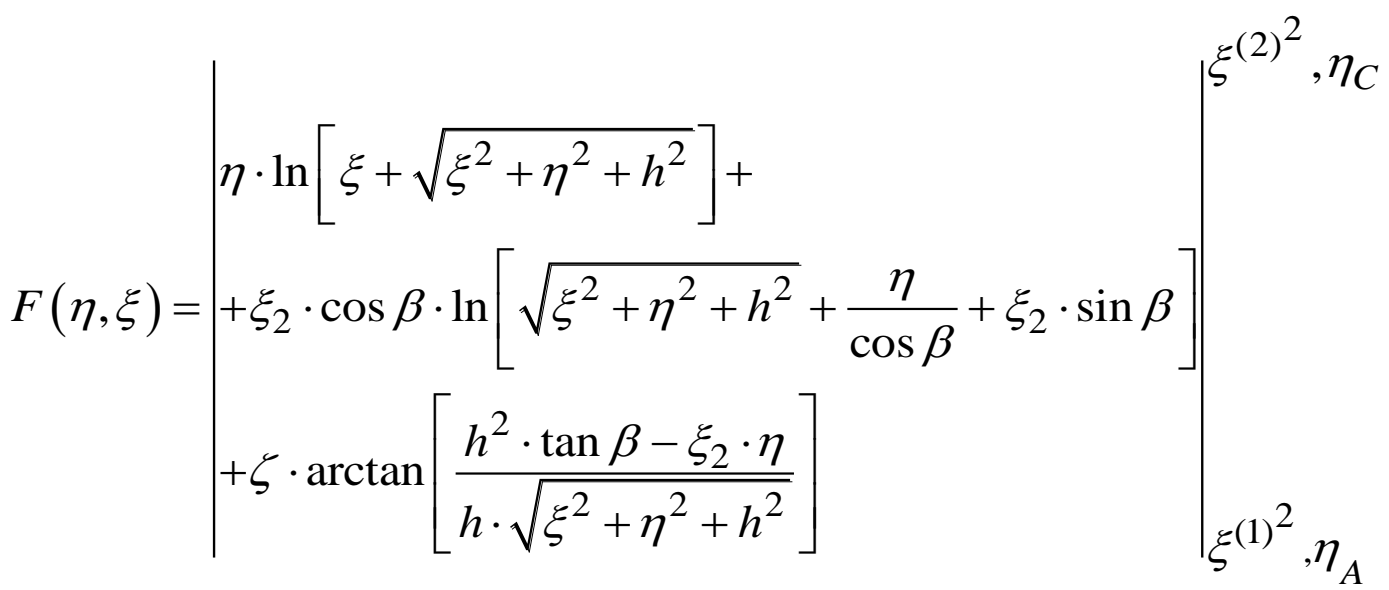

$Y$ is defined for the whole triangles pyramid as follows Eq.(4),

$$
\begin{aligned}
Y= & F_{1}\left(\eta_{C}, \xi^{(2)}\right)-F_{2}\left(\eta_{A}, \xi^{(2)}\right) \\
& -F_{3}\left(\eta_{C}, \xi^{(1)}\right)+F_{4}\left(\eta_{A}, \xi^{(1)}\right)
\end{aligned}
$$

$Y$ is defined as shown below while parameters are particularly used;

$$
\begin{aligned}
& Y=\left\{\eta_{C} \cdot \ln \left[\xi_{C}+\overline{O C}\right]+\xi_{2} \cdot \cos \beta \cdot\right. \\
& \ln \left[\overline{O C}+\frac{\eta_{C}}{\cos \beta}+\xi_{2} \cdot \sin \beta\right]+h \cdot \arctan \left[\frac{h^{2} \cdot \tan \beta-\xi_{2} \cdot \eta_{C}}{h \cdot \overline{O C}}\right] \\
& -\eta_{A} \cdot \ln \left[\xi_{B}+\overline{O B}\right]-\xi_{2} \cdot \cos \beta \\
& \ln \left[\overline{O B}+\frac{\eta_{A}}{\cos \beta}+\xi_{2} \cdot \sin \beta\right]-h \cdot \arctan \left[\frac{h^{2} \cdot \tan \beta-\xi_{2} \cdot \eta_{A}}{h \cdot \overline{O B}}\right] \\
& -\eta_{C} \cdot \ln \left[\xi_{C}+\overline{O C}\right]-\xi_{1} \cdot \cos \alpha \cdot \\
& \ln \left[\overline{O C}+\frac{\eta_{C}}{\cos \alpha}+\xi_{1} \cdot \sin \alpha\right]-h \cdot \arctan \left[\frac{h^{2} \cdot \tan \alpha-\xi_{1} \cdot \eta_{C}}{h \cdot \overline{O C}}\right] \\
& +\eta_{A} \cdot \ln \left[\xi_{A}+\overline{O A}\right]+\xi_{1} \cdot \cos \alpha \cdot \\
& \left.\ln \left[\overline{O A}+\frac{\eta_{A}}{\cos \alpha}+\xi_{1} \cdot \sin \alpha\right]+h \cdot \arctan \left[\frac{h^{2} \cdot \tan \alpha-\xi_{1} \cdot \eta_{A}}{h \cdot \overline{O A}}\right]\right\}
\end{aligned}
$$

$$
\Delta U=\frac{1}{2} G \cdot \rho \cdot(h \cdot Y)
$$

' $G$ ' is gravity constant and ' $h$ ' is the height of the tetrahedron see Fig. 2.

The gravity effect of the polyhedron is given by the vertical derivative of the potential effect.

$$
\Delta g=\frac{\partial}{\partial z}(\Delta U)
$$

with derivatives of open expression;

$$
\Delta g=\frac{1}{2} G \cdot \rho\left\{\frac{\partial}{\partial z}(h) \cdot Y+\frac{\partial}{\partial z}(Y) \cdot h\right\}
$$

Normal unit vector of the vertical (z) component

$$
\hat{\zeta}_{z}=\frac{\partial}{\partial z}(h)_{\text {ve }} Y^{\prime}=\frac{\partial}{\partial z}(Y)
$$

is written;

$$
\Delta g=\frac{1}{2} G \cdot \rho \cdot \sum_{i=1}^{n}\left(\hat{\zeta}_{z_{i}} \cdot Y_{i}+Y_{i}^{\prime} \cdot h_{i}\right)
$$

Gravity potential; 


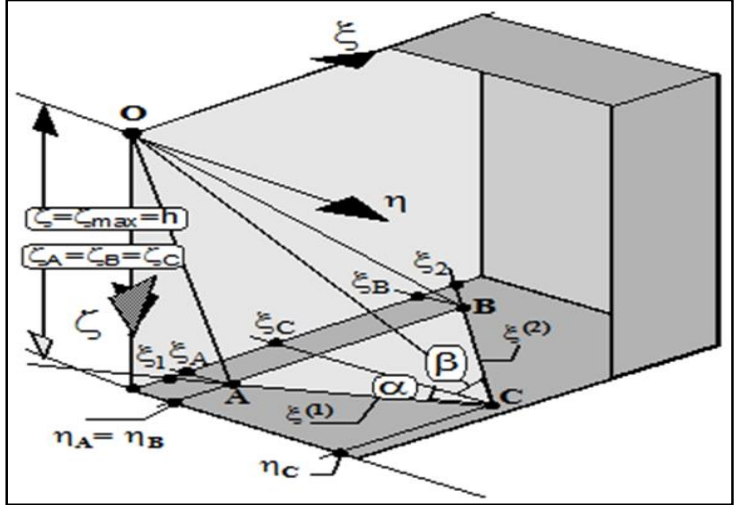

Figure 1. The model geometry is created between triangle mass surface (triangle pyramid) and observation point.

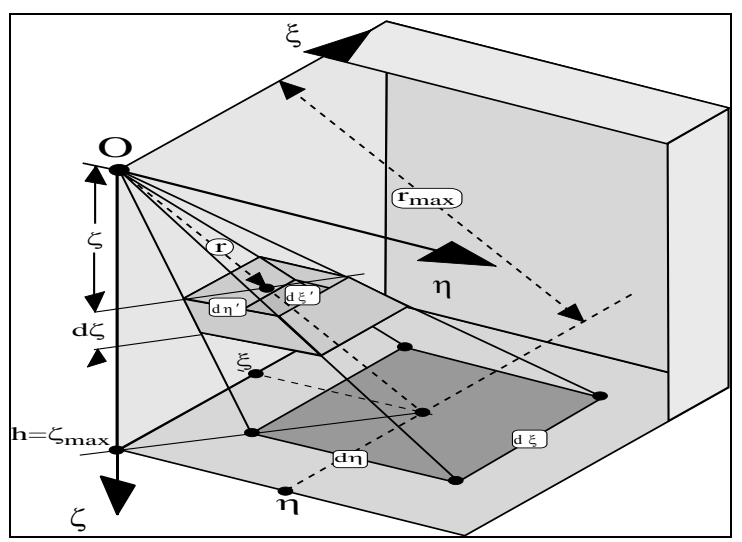

Figure 2. Schematic illustration and parameters of the integration in Eq. (1).

\subsection{D Gravity Inversion}

The inversion procedure performs the smallest sum of the squares of the difference between the observed and calculated values, the least squares method, forms the basis of the inversion procedure. System of equations are solved using linear or nonlinear solutions. In this study, formation density is taken into consideration as constant. That is a linear solution is implemented. By taking derivatives of the squares of the difference between the observed and calculated values according to parameters, derivative equations is equal to zero. So, it is intended to perform the smallest mistake.

$l_{1}, l_{2}, l_{3}$ are taken into consideration to be measurement values,

$$
\begin{aligned}
& l_{1}=\mathrm{a}_{1} \mathrm{x}+\mathrm{b}_{1} \mathrm{y}+\mathrm{c}_{1} \mathrm{z} \\
& l_{2}=\mathrm{a}_{2} \mathrm{x}+\mathrm{b}_{2} \mathrm{y}+\mathrm{c}_{2} \mathrm{z} \\
& \vdots
\end{aligned}
$$

$$
l_{\mathrm{n}}=\mathrm{a}_{\mathrm{n}} \mathrm{x}+\mathrm{b}_{\mathrm{n}} \mathrm{y}+\mathrm{c}_{\mathrm{n}} \mathrm{z}
$$

a small error is made absolutely in measurements. These errors must be added to the equation.

Errors are placed to measurement equations,

$$
\begin{aligned}
& l_{1}=\mathrm{a}_{1} \mathrm{x}+\mathrm{b}_{1} \mathrm{y}+\mathrm{c}_{1} \mathrm{z}+\vartheta_{1} \\
& l_{2}=\mathrm{a}_{2} \mathrm{x}+\mathrm{b}_{2} \mathrm{y}+\mathrm{c}_{2} \mathrm{z}+\vartheta_{1} \\
& \vdots \\
& l_{\mathrm{n}}=\mathrm{a}_{\mathrm{n}} \mathrm{x}+\mathrm{b}_{\mathrm{n}} \mathrm{y}+\mathrm{c}_{\mathrm{n}} \mathrm{z}+\vartheta_{\mathrm{n}}
\end{aligned}
$$

$\vartheta_{n}$ error amounts is put to the left side of the equations,

$$
\begin{aligned}
& \vartheta_{1}=l_{1}-\mathrm{a}_{1} \mathrm{x}-\mathrm{b}_{1} \mathrm{y}-\mathrm{c}_{1} \mathrm{z} \\
& \vartheta_{2}=l_{2}-\mathrm{a}_{2} \mathrm{x}-\mathrm{b}_{2} \mathrm{y}-\mathrm{c}_{2} \mathrm{z} \\
& \vdots \\
& \vartheta_{\mathrm{n}}=l_{\mathrm{n}}-\mathrm{a}_{\mathrm{n}} \mathrm{x}-\mathrm{b}_{\mathrm{n}} \mathrm{y}-\mathrm{c}_{\mathrm{n}} \mathrm{z}
\end{aligned}
$$

the aim is to zero the sum of the error.

$$
\sum_{i=1}^{n} \vartheta_{n}=0
$$

for this process in mathematics

$$
\sum_{i=1}^{n}\left(\vartheta_{i}^{2}\right)=\min
$$

if this equality is written in the general case

$$
\sum_{\mathrm{i}=1}^{\mathrm{n}}\left(\vartheta_{\mathrm{i}}^{2}\right)=\sum\left(l_{\mathrm{i}}-\mathrm{a}_{\mathrm{i}} \mathrm{x}-\mathrm{b}_{\mathrm{i}} \mathrm{z}-\mathrm{c}_{\mathrm{i}} \mathrm{y}\right)^{2}=\min
$$

then

$$
\begin{aligned}
& {[\vartheta . \vartheta]=[\mathrm{aa}] \mathrm{x}^{2}+2[\mathrm{ab}] \mathrm{xy}+2[\mathrm{ac}] \mathrm{xz}} \\
& -2[\mathrm{a} l] \mathrm{x}+[\mathrm{bb}] \mathrm{y}^{2}+2[\mathrm{bc}] \mathrm{yz}-2[\mathrm{~b} l] \mathrm{y} \\
& \ldots+[\mathrm{cc}] \mathrm{z}^{2}-2[\mathrm{cl}] \mathrm{z}+[l l]=\min
\end{aligned}
$$

partial derivatives are got as to the unknown and are equaled to zero,

$$
\begin{aligned}
& \frac{\partial(\vartheta \vartheta)}{\partial \mathrm{x}}=2[\mathrm{aa}] \mathrm{x}+2[\mathrm{ab}] \mathrm{y}+2[\mathrm{ac}] \mathrm{z}-2[\mathrm{al}]=0 \\
& \frac{\partial(\vartheta \vartheta)}{\partial \mathrm{y}}=2[\mathrm{ab}] \mathrm{x}+2[\mathrm{bb}] \mathrm{y}+2[\mathrm{bc}] \mathrm{z}-2[\mathrm{bl}]=0 \\
& \frac{\partial(\vartheta \vartheta)}{\partial \mathrm{z}}=2[\mathrm{ac}] \mathrm{x}+2[\mathrm{bc}] \mathrm{y}+2[\mathrm{cc}] \mathrm{z}-2[\mathrm{cl}]=0
\end{aligned}
$$

equation is rearranged, 


$$
\begin{aligned}
& {[a a] x+[a b] y+[a c] z=[a l]} \\
& {[b a] x+[b b] y+[b c] z=[b l]} \\
& {[c a] x+[c b] y+[c c] z=[c l]}
\end{aligned}
$$

Where (al), (bl) and (cl) are known gravity measurements, (aa), (ab), (ac), (ba), (bb), (bc), (ca), (cb) and (cc) are matrix factors, $\mathrm{x}$ is function constant, and $\mathrm{y}$ and $\mathrm{z}$ are mass densities.

The matrix is obtained from the steps of the process. This matrix can be solved with various solution methods. For example, the equation systems can be solved by the method of gauss elimination (See Eq.19).

\subsection{Comparison of the 2D-3D Gravity Calculations in Cartesian Coordinates}

First, a seam shaped model mass is designed as the model mass. In order to avoid the influence of boundary, the borders of mass are extended for $\pm 3000 \mathrm{~km}$ as parallel to earth's surface. When measuring network is created, the calculation profile is considered on falls into center profile of model mass. The model mass and the measurement network on this mass are created. In this part of working, a seam shaped model mass of which intensity is $3.7 \mathrm{gr} / \mathrm{cm}^{3}$ extends in the surrounding rock of which intensity is 2.7 $\mathrm{gr} / \mathrm{cm}^{3}$ is designed. Here, as the intensity difference is $1.0 \mathrm{gr} / \mathrm{cm}^{3}$. The accuracy of algorithms of computer program which perform 2D and 3D calculation are tested. For this purpose, vertical cross-section under $\mathrm{y}=0$ profile is extended to $\pm \infty$ in $\mathrm{y}$ direction as parallel to earth's surface, gravity is calculated by $2 \mathrm{D}$ algorithm for density difference to give $1.0 \mathrm{gr} / \mathrm{cm}^{3}$. Then, vertical cross-section under $\mathrm{y}=0$ profile is extended to $\pm 3000 \mathrm{~km}$ in $\mathrm{y}$ direction as parallel to earth's surface, gravity is calculated by 3D algorithm for density difference to give $1.0 \mathrm{gr} / \mathrm{cm}^{3}$. In both cases, the maximum gravity value is 16.88491 $\mathrm{mGal}$. Also the minimum gravity value is found as $0.01479 \mathrm{mGal}$. The found 2D and 3D gravity values are compared (Table 1). Calculated gravity values for test for both cases are seen on Fig. 3. In the original 3D model geometry, mass limits are extended to $\pm 3000 \mathrm{~km}$ in y direction as parallel to earth's surface, gravity is calculated by 3D algorithm for density difference to give $1.0 \mathrm{gr} / \mathrm{cm}^{3}$.

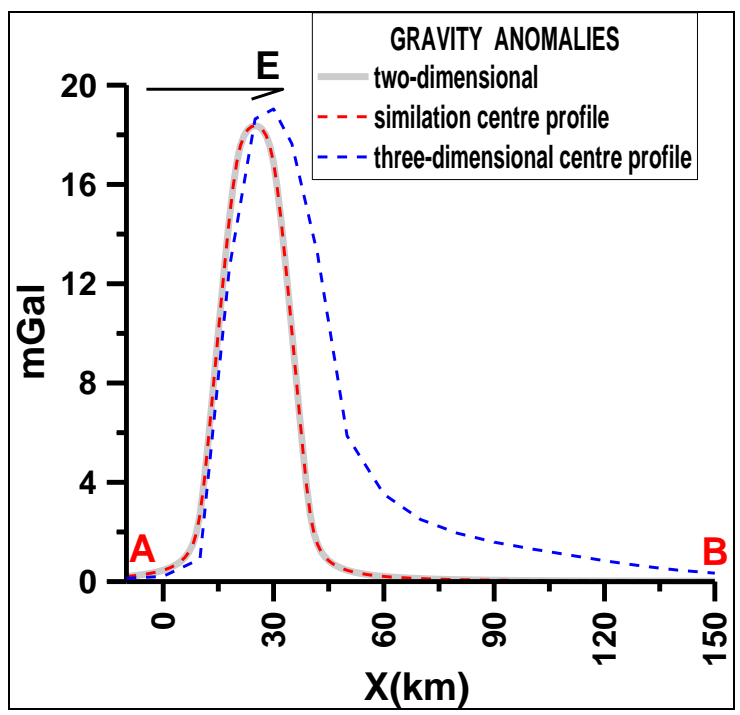

Figure 3 . The gravity of seam mass model on the (A B) centre profiles of the gravity values over the middle profiles which are derived from $2 \mathrm{~B}$, similation 3D and original 3D models.

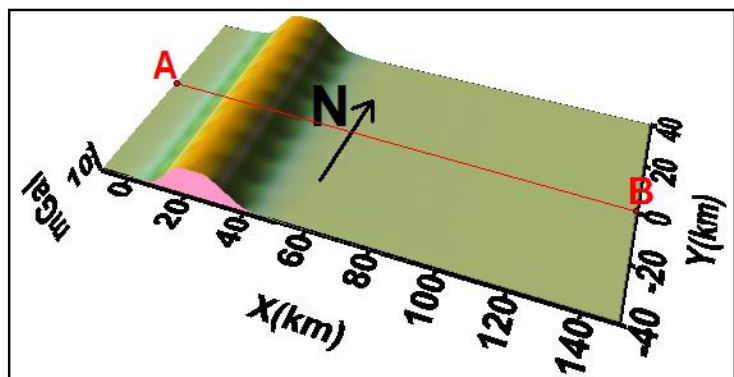

Figure 4. The gravity of similation 3D model of seam mass model.

Here, calculated Bouguer gravity anomaly is adopted as the measure values, and these values are applied separately to models and densities are found individually by inversion. Calculated maximum gravity value is $79.74457 \mathrm{mGal}$ and minimum gravity value is $0.01479 \mathrm{mGal}$. Also, these values can be seen on the $\mathrm{y}=0$ profile from calculated gravity values on Fig. 4 . All these values are shown in Table 1. 3D simulation model geometry is created. Gravity values from agreed measure values on $\mathrm{y}=0$ profile are given both the 2D and 3D similation. The calculated density is $0.8581 \mathrm{gr} / \mathrm{cm}^{3}$, maximum gravity value is $19.04175 \mathrm{mGal}$ and minimum gravity value is $0.12976 \mathrm{mGal}$. The average error is $3.0997 \mathrm{mGal}$ in both calculations. Here, the difference of intensity is shown. In addition to calculated Bouguer 
anomaly from the original 3D model, as measure values, in order to perform inversion, is given again to the original 3D model itself. Obtained 3D gravity anomaly and 3D similation model geometry of this anomaly can be shown in Fig. 4 and Fig. 5. 3D gravity anomaly and 3D original model geometry can be shown in Fig. 6 and Fig. 7.

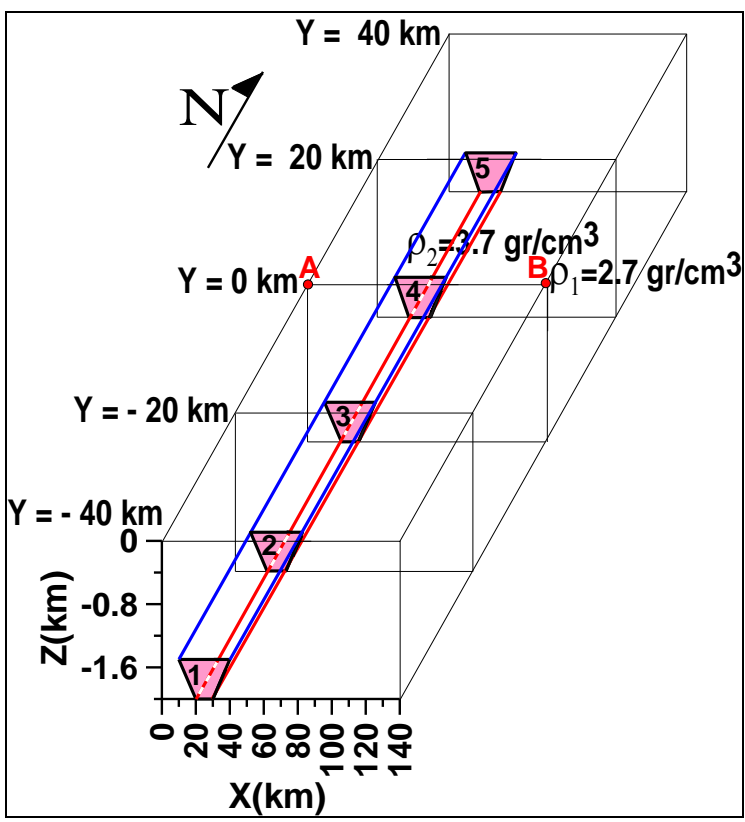

Figure 5. The design of similation 3D model of seam mass model.

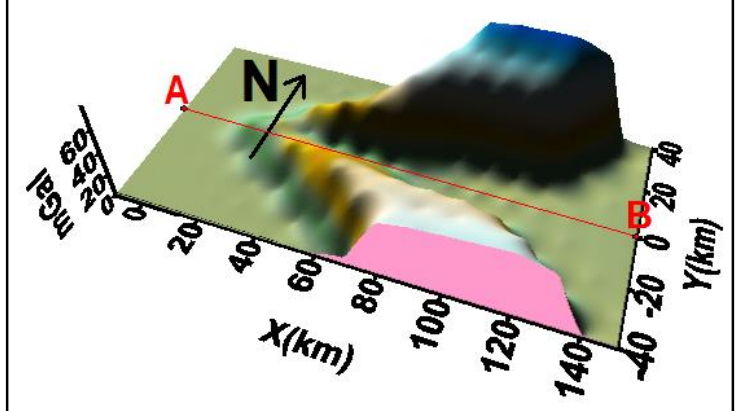

Figure 6. The gravity anomaly of original 3D model of seam shaped model mass.

Table 1. All values of seam shaped model mass

\begin{tabular}{|c|c|c|c|c|c|c|}
\hline \multicolumn{7}{|c|}{ THE SEAM MASS MODEL VALUES ON THE (A B) CENTRE PROFILES } \\
\hline \multirow[b]{2}{*}{ UNIT } & \multicolumn{3}{|c|}{ FORWARD } & \multicolumn{3}{|c|}{ INVERSION } \\
\hline & 2D M1 & $\begin{array}{l}\text { SIMIL. } \\
\text { 3D M2 }\end{array}$ & $\begin{array}{l}\text { ORJG. } \\
\text { 3D M3 }\end{array}$ & 2D M1 & $\begin{array}{l}\text { SIMIL. } \\
\text { 3D M2 }\end{array}$ & $\begin{array}{l}\text { ORJG. } \\
\text { 3D M3 }\end{array}$ \\
\hline $\begin{array}{l}\text { Density } \\
\text { (gr/cm3) }\end{array}$ & 1.000 & 1.000 & 1.000 & 0.8581 & 0.8581 & 1.000 \\
\hline $\begin{array}{l}\text { Max } \\
\text { value } \\
\text { (mGal) }\end{array}$ & 16.88491 & 16.88491 & 79.74457 & 19.04175 & 19.04175 & 79.74457 \\
\hline $\begin{array}{l}\text { Min } \\
\text { value } \\
\text { (mGal) }\end{array}$ & 0.01479 & 0.01479 & 0.09669 & 0.12976 & 0.12976 & 0.09669 \\
\hline
\end{tabular}




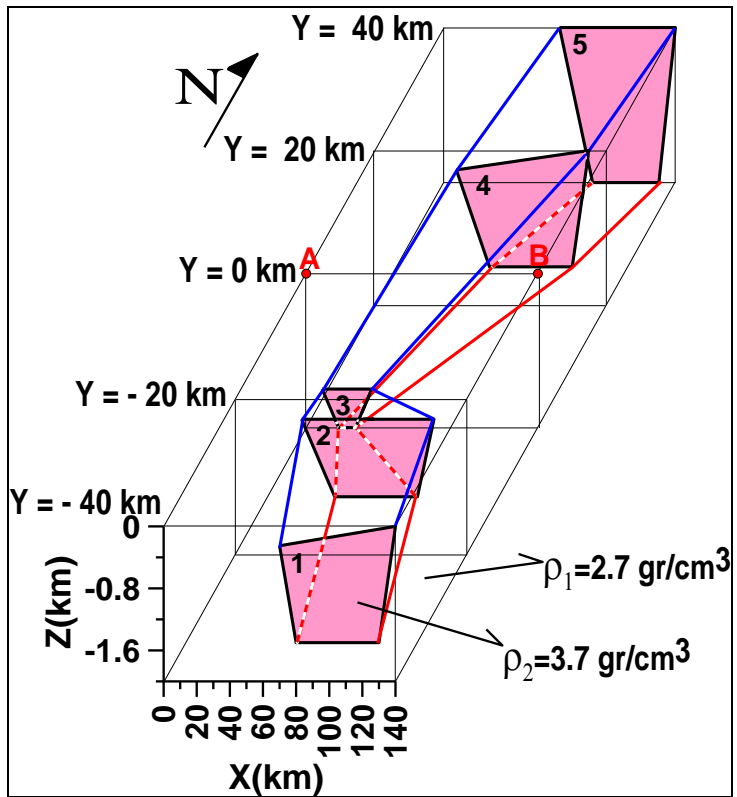

Figure 7. The design of original 3D model of seam shaped model mass.

\subsection{Comparison of the 3D Gravity Calculations in Cartesian Spherical Coordinates}

In the use of cartesian coordinates in 3D gravity calculations, the calculation points from a distance, away from the earth by growing in size, are suspended outside of the earth as shown in figure 10. Also, very large formations way out of the real shapes (Fig. 8). Therefore, with using spherical coordinates, also the slope of the land would have been included in the calculation (Fig. 9). To explain this, a hollow of mass square is taken as an example model. The mass of the $\mathrm{x}$-direction is taken $\pm 1000 \mathrm{~km}$ in length, $\mathrm{y}$ direction is $\pm 1000 \mathrm{~km}$ in length, the depth of the upper surface is $0 \mathrm{~km}$ and the depth of the sub-surface is $-350 \mathrm{~km}$. Density is taken as $1 \mathrm{gr} / \mathrm{cm}^{3}$. This mass is defined firstly in cartesian coordinates and the gravity anomaly of mass is calculated in cartesian coordinates as $3 \mathrm{D}$. Then it is defined in spherical coordinates for the 3D gravity values are calculated and these values are compared (Table 2). In addition, the lengths of the surface of the mass in the $x$ and $y$ direction, vertical direction of the depth, the results of the performed calculations in cartesian coordinates and spherical coordinates can be seen Fig. 10.

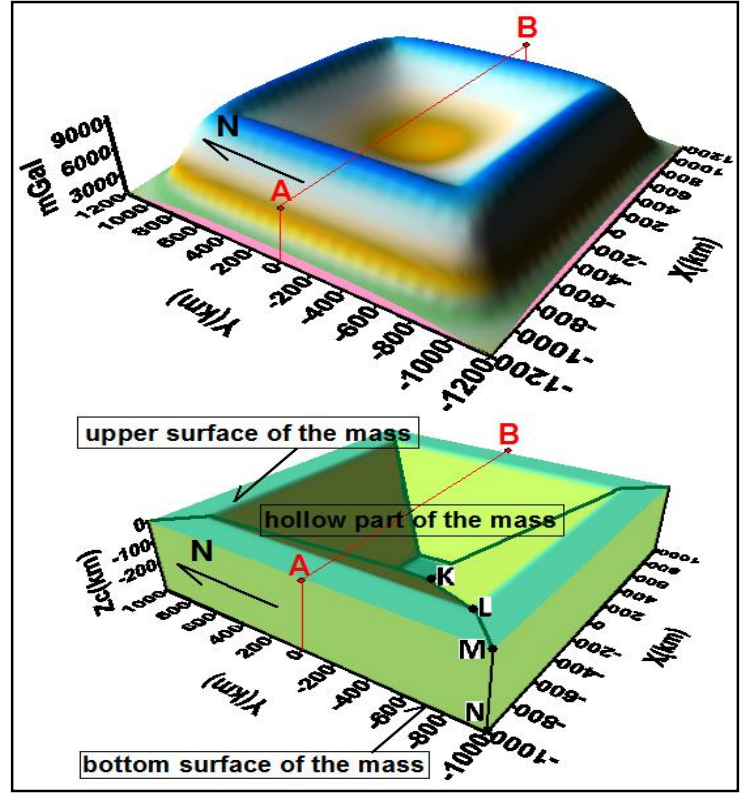

Figure 8. The mass model in cartesian coordinates(beneath) and the gravity anomaly of this mass model(above).

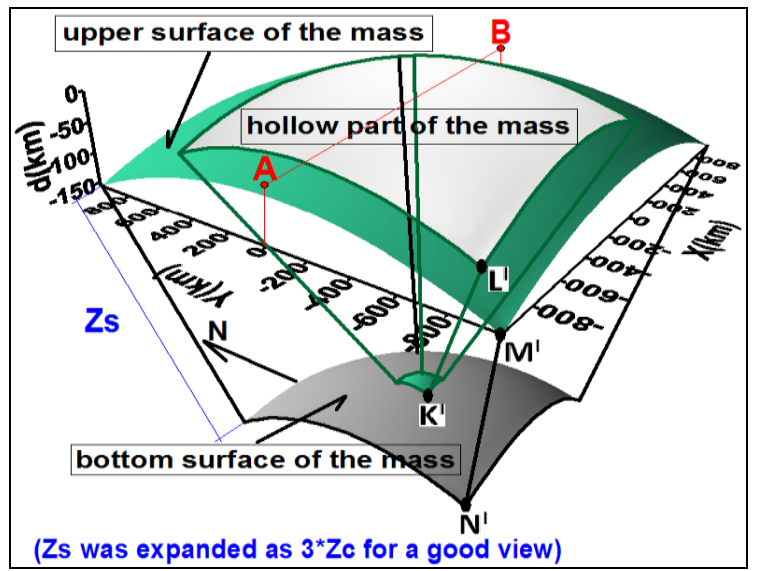

Figure 9. The mass model in spherical coordinates.

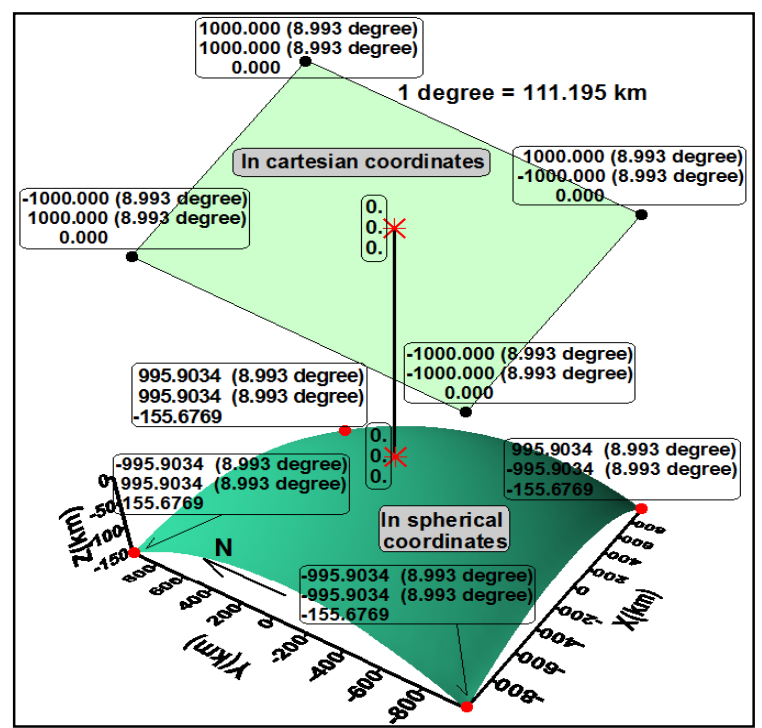

Figure 10. In spherical coordinates of a surface defined to cartesian coordinates formed shape. 
Table 2. As 3D calculations comparison of values on $\mathrm{Y}=0$ (middle) profile in cartesian-spherical coordinates

\begin{tabular}{|c|c|c|c|}
\hline $\begin{array}{l}\text { THE RESULT OF } \\
\text { CALCULATION } \\
\text { (density : } 1 \mathrm{gr} / \mathrm{cm}\end{array}$ & CARTESIAN 3D & $\begin{array}{l}\text { THE RESULT } 0 \\
\text { CALCULATION } \\
\text { (density : } 1 \mathrm{gr} / \mathrm{cm}\end{array}$ & SPHERICAL 3D \\
\hline $\mathrm{X}(\mathrm{km})$ & Gravity (mGal) & DEGREE & Gravity (mGal) \\
\hline-1000.00 & 6116.57 & -8.99 & 5776.92 \\
\hline-800.00 & 9666.54 & -7.19 & 8481.21 \\
\hline-600.00 & 7130.57 & -5.40 & 7295.16 \\
\hline-400.00 & 5175.53 & -3.60 & 5866.68 \\
\hline-200.00 & 3930.46 & -1.80 & 4891.71 \\
\hline 0.00 & 3517.82 & 0.00 & 4552.33 \\
\hline 200.00 & 3930.46 & 1.80 & 4891.71 \\
\hline 400.00 & 5175.53 & 3.60 & 5866.68 \\
\hline 600.00 & 7130.57 & 5.40 & 7295.16 \\
\hline 800.00 & 9666.54 & 7.19 & 8481.21 \\
\hline 1000.00 & 6116.57 & 8.99 & 5776.92 \\
\hline \multicolumn{2}{|c|}{ VOLUME : $1059333333.333 \mathrm{~km} 3$} & \multicolumn{2}{|c|}{ VOLUME : $1032295281.105 \mathrm{~km} 3$} \\
\hline
\end{tabular}

\section{Discussion and Conclusions}

3D gravity model calculations are made instead of 2D, more valid results are reached. However, although 3D model calculations, if the formations are very large, also in this case the world curvature to be taken into consideration is mandatory. This can be possible only by using the spherical coordinates. Also very good way of the world's inclination to be included in the calculation, the surfaces of the masses to be necessary directions and locations, be taken as often as possible, which should be defined with spherical coordinates. In case of very complex mass, 2D gravity study gives very different results from the search results. In large-scale, 3D gravity study in cartesian coordinates gives very different results from the search results. In such cases, 3D gravity study in spherical coordinates is mandatory. After that, keep the light on the work with the expectation of this study take into consideration the points mentioned above, the results is better demonstrated.

\section{Conflict Of Interest}

No conflict of interest was declared by the authors.

\section{References}

[1] Akçığ, Z., Pınar,R., 1994, "Gravite Manyetik Arama Yöntemleri", Mühendislik Fakültesi Basım Ünitesi, İzmir.

[2] Çavşak, H., 1992, "Dichtemodelle für den mitteleuropäischen Abschnitt der EGT aufgrund der gemeinsamen Inversion von Geoid, Schwere und refraktionsseismisch ermittelter Krustenstruktur (in German). Density models for the central European Section of EGT on the basis of joint inversion of geoid, gravity and refraction seismic crustal structure)", Ph.D. Thesis, Mainz University.

[3] Çavşak, H., 2008, "Gravity effect of spreading ridges - comparison of 2D and spherical models", Marine Geophysical Researches, Volume 29, Number 3, $161,165$.

[4] Çavşak, H., 2010, "The Effects of the Earth's Curvature on Gravity and Geoid Calculations" Pure and Applied Geophysics, DOI 10.1007/s00024-0110353-8.

[5] Çavşak, H., 2011, "Effective calculation of gravity effects of uniform triangle polyhedra", Studia Geophysica et Geodaetica, DOI SGEG-2011-0004.R1.

[6] Çavşak, H., and Elmas, A., 2010, "3D Modeling Of Gravity Anomalies Using 2D 
Synthetic Models", SDÜ Journal of Engineering Science and Design Vol:1, No:2, 79-86.

[7] Çavşak, H., and Elmas, A., 2011, "Crust Studying in the Eastern Pontides by 3D Gravity Algorithm", e-Journal of New World Sciences Academy, Vol:6, No:3, No: 4A0041.

[8] Çavşak, H., Jacoby, W., R., 2004, “Threedimensional modelling of crust und upper Mantle For the eastern Pondites and Black Sea Basin", Türkiye 16. Uluslararası Jeofizik Kongre ve Sergisi, 7-10 Aralık Bildiri Özetler Kitabı, Ankara.

[9] Çavşak, H., and Jacoby, W., R., 2005, "Inversiyon of Gravity Anomalies Over Spreading Oceaning Ridges". J. Geodynamics, 39, 461-474.

[10] Çavşak, H., Jacoby, W., R., ve Seren, A., 2002, "Eastern Pontides and Black Sea gravity inversion, crustal structure, isostasy and geodynamics", Geodynamics, $33,201-218$.

[11] Elmas, A., 2012, “3B Gravite İnversiyon Hesaplarında Sismik Hız Sinırlarının da Kullanılmasıyla Yoğunluğun Derinlikle Değişiminin Tespiti", Doktora Tezi, KTÜ, Trabzon.
[12] Erden, F., 1979, "Uygulamalı Gravite", Eğitim Serisi No. 21, Maden Tetkik ve Arama Enstitüsü Yayınlarından, Ankara.

[13] Ergin, K., 1973, "Uygulamalı Jeofizik", Üçüncü Baskı, Özarkadaş Matbaası, İstanbul.

[14] Jacoby, W.R., Smilde, P., 2009, “Gravity Interpretation: Fundamentals and Application of Gravity Inversion and Geological Interpretation", Springer, US.

[15] Sanver, M., İsssever, T., 2007, “Gravite ve Manyetik Arama Yöntemleri”, Birinci Baskı, Nobel Basımevi, Ankara.

[16] Talwani, M., Worzel, J., L., and Landsman, M., 1959, "Rapid Gravity Computations for Two-Dimensional Bodies with Aplications to The Mendiciono Submarine Fracture Zone", J. Geophys. Res., 64, 49-59.

[17] Telford, W.M., Geldart, L. P., Sheriff, R. E., Keys, D. A., 1981, "Applied Geophysics", First Edition, Cambiridge University, New York. 